\title{
( Minimum Wage in Readymade Garments aße Industry in Bangladesh
}

\author{
Mohammad Hasan \\ Executive Director, Babylon Group, Dhaka, BANGLADESH \\ E-mail for correspondence: mohammadhasanbg@gmail.com
}

\begin{abstract}
Manufacturing Ready-Made Garment (RMG) is labour intensive and low wage based industry. Nowhere, this industry was static or permanent basically on account of wage. As soon as any country became developed, the apparel and textile industry left that country. RMG is highly focused on the relocation of production. The relocation take place from high wage regions to low cost production regions just like water flows down-stream always. This single sector is dominating Bangladesh economy Since '80s. In Bangladesh different sectors have different wage levels according to the nature of job. The Minimum Wages Board recommended or rerecommended minimum wages of the 42 industrial sectors. The minimum wage of this very sector is lower than other sectors within the country and among the RMG manufacturing countries as well. On the contrary, within the country, for the same sector - RMG, there are dissimilarity in the minimum wage. Bangladesh Export Processing Zone Authority (BEPZA) declares the same for the industries inside Export Processing Zones (EPZ) which is higher than the declaration by Minimum Wage Board for outside EPZ factories. Minimum wage board has classified the non-EPZ workforces into seven grades according to their skills with seven different wage levels. Contrary, EPZs workers are divided into five categories. BEPZA has fixed higher wages and benefits compere to non-EPZ factories. Moreover, the study finds that the grading system has many loopholes which is not based on well thought and planned. There are so many posts and positions required to run an RMG factory that are not mentioned in the gazette. There is no guideline on how to measure workers' competency for a particular grade and for how long a worker will be retained in the same grade. These loopholes are helping the employers to manipulate in determining workers' grade. Minimum wage structure is applicable for whose positions mentioned in the gazette and entitled to all types of benefits mentioned in the law including overtime (OT) payment at double rate of wage. To avoid extra overtime payment factory management promotes or changes the designations like executive, supervisor etc. who are getting comparatively higher wage to keep them away from OT benefits. All those anomalies need to be addressed for properly.
\end{abstract}

Keywords: Minimum Wage, RMG, Least Developed Countries, Bangladesh

\section{INTRODUCTION}

Yarn and cloth became the mainstream industry with the invention of flying shuttle by John Kay in 1734 CE in England. The first functional sewing machine was invented by a French tailor, Barthelemy Thimonnier in 1830. The role of the sewing machine in shaping global capitalism was very pivotal. Karl Marx named the sewing machine as the 'decisively revolutionary machine.' At the time of invention both flying shuttle and the sewing machine faced severing protest by the workers who feared imminent unemployment. Instead of job loss, after 150 years, this innovation has created thousands of hundreds of jobs in developing and least developing countries. Those decisively revolutionary invention has been making a fortune for the few entrepreneurs and their associates. On the contrary, sewing machines operators, the largest section of the sector, have been struggling to meet their basic needs, job security and workplace standard. In readymade garment (RMG) sector, the wage is one of the core issues of labor unrest. Most of the recent turmoil in RMG sector took place on wage related ground.

The country's largest, in all aspects, manufacturing industry gets hurt at regular intervals. The human resources behind the machines have to demonstrate in the busy streets, block roads, vandalize cars, throw stones or brick chips at his/her work places, chase law enforcer agencies to give a message of their demand to their owners. Anything that goes wrong with Bangladesh, be it human-made or natural, becomes a major and immediate concern of developed world as their apparel business ties with one of the members of a Least Developed Countries (LDC) like Bangladesh. So any unrest in Bangladesh 
RMG (Readymade Garments) industry or other areas like politics, flood, cyclone, etc. makes our business partners concerned about their investment. In regular intervals workers of RMG are being focused on the spotlight of international media because of their violent protest to materialize fair demand - wage adjustment. After serious and series of confrontations, damaging industrial relationship and image of the country, a temporary solution is being taken. Parties concerned, business associations or government, are not willing to find out the causes, resulting having no permanent solution to the unrest. Why the workers have to raise hands and voices to materialize even their basic and very logical demand. The prices of daily essentials go up every weekend, the utility bills and house rents go up, but wages remain unchanged. Devaluation of Bangladesh currency (BDT) with USD, which gives direct benefit to the makers, harms workers worst as the price of daily essentials goes up as they are not any part of owners' benefit due to currency devaluation. Without sufficient income, leisure time and entertainment, how the mainstream workers will be physically and mentally fit to come back to work the next morning? On the contrary, wage increase will not be enough to make our workers happy, if the prices go up at present ratio. The government has the responsibility to control the price of daily necessities. Buyers who are upholding the ethical trading in their Code of Conducts, how far are they ethical to offer to price a labor? To them labor cost is less important than material cost. To earn more profit the buyers add design in their style and manufacturers use different techniques to enhance productivity, but the fight for "minimum" wage goes on. This unethical practice by the buyers and makers can be considered as an unholy marriage between the two aforementioned stakeholders, where workers are in endless resentment. The rate of minimum wage of our country is one of the lowest among the competitors' countries. Is the International Labor Organization (ILO) and others labor rights watchdog not responsible for justifying our labor cost?

\section{The Concept OF Minimum Wage AND INTERNATIONAL DECLARATIONS}

Both salary and wage have different meanings. But sometimes the terms are used interchangeably. When one is paid, against his/her job, on monthly or yearly is referred as Salary. On the contrary, wage is being paid per hour or weekly, which means that one has to be present and working for getting payment. The payment in RMG, like other sectors, for both the workers and employees, is being made monthly basis. The workers of garment sector are not paid hourly or weekly. They are being paid monthly, for 26 days of work in a month and six days in a week, eight hours a day. The fixation of their lowest limit of compensation by the government's competent authority is called minimum wage.

Organized labor movement demanding higher wages and shorter working hours is historical. The industrial revolution and evolution of labor unions to protect workers' interest are part and parcel of this industry. From farm workers to ind ustrial laborers, they have to have their wage hike after going on strike, protest etc. In the history of labor, not a single logical demand was met by them without movement. The workers materialized their right to limit working time to eight hours after the sacrifices of many lives on $1^{\text {st }}$ May in 1886 . The year 1912 is remarkable in labor history as minimum-wage laws were formulated and passed for the first time in the Massachusetts, United States and applied only to women and children. These laws specify the minimum amount that employers may pay their employees for doing a specified type of work. To address the drawbacks of rapid industrialization and urbanization, the concept of minimumwage gained popularity among the progressive people and that period was known as the Progressive Era (1890 - 1920). The hourly wages at that time were often below to meet the basic needs for livelihood.

\section{ILO CONVENTION}

In 1928 in its general conference, International Labor Organization (ILO) adopted the Convention No. 26 and Recommendation No. 30 to create or maintain machinery to fix the minimum rates of wages for the workers in trades/industries where no arrangement exists for effective regulation of payment. The International Labor Organization (ILO) defines minimum wage as "the minimum sum payable to a worker for work performed or services rendered, within a given period, whether calculated on the basis of time or output, which may not be reduced either by individual or collective agreement, which is guaranteed by law and which may be fixed in such a way as to cover the minimum needs of the worker and his or her family, in the light of national economic and social conditions" (BILS, 2016).

Article 1 of C26 - Minimum wage- Fixing Machinery Convention, 1928 declares "Each Member of the International Labor Organization which ratifies this Convention undertakes to create or maintain machinery whereby minimum rates of wages can be fixed for workers employed in certain of the trades or parts of trades (and in particular in home working trades) in which no arrangements exist for the effective regulation of wages by collective agreement or otherwise and wages are exceptionally low" (ILO, 1996).

Article 3 of C131 - Minimum Wage Fixing Convention, 1970 describes "The elements to be taken into consideration in determining the level of minimum wages shall, so far as possible and appropriate in relation to national practice and conditions, include-

(a) The needs of workers and their families, taking into account the general level of wages in the country, the cost of living, social security benefits, and the relative living standards of other social groups;

(b) Economic factors, including the requirements of economic development, levels of productivity and the desirability of attaining and maintaining a high level of employment" (ILO, 1996).

\section{United Nations the Universal Declaration of HumAN RIGHTS}

The Universal Declaration of Human Rights was adopted by the UN General Assembly on 10 December 1948. In its article 23, clause 3 and article 25, clause 1 "describe about favorable remuneration and the right to a standard of living. 


\section{Article 23}

- Everyone has the right to work, to free choice of employment, to just and favorable conditions of work and to protection against unemployment.

- Everyone, without any discrimination, has the right to equal pay for equal work.

- Everyone who works has the right to just and favorable remuneration ensuring for himself and his family an existence worthy of human dignity, and supplemented, if necessary, by other means of social protection.

Article 25

- Everyone has the right to a standard of living adequate for the health and well-being of himself and of his family, including food, clothing, housing and medical care and necessary social services, and the right to security in the event of unemployment, sickness, disability, widowhood, old age or other lack of livelihood in circumstances beyond his control" (UDHR,1948).

\section{Minimum Wage BoARD, Bangladesh}

In Bangladesh, the first minimum wage board was constituted in 1959 under the recommendation of ILO convention no. 131. From then, the Minimum Wages Board is the only statutory wage-fixing authority in Bangladesh. Minimum Wages Board is a department under the Ministry of Labor and Employment and authorized body of the country who finalizes the minimum rates of wages of workers of privately-owned industrial undertakings. After the establishment of the Minimum Wages Board, it recommended or re-recommended minimum wages of the 42 industrial sectors. In Bangladesh, different sectors have different wage levels according to the sectors essence and job nature. On the contrary, Bangladesh Export Processing Zone Authority (BEPZA) declares the same for the industries inside Export Processing Zones (EPZ).

\section{The Constitution of the Peoples' Republic Bangladesh}

Article 28 of the Constitution stated as follows-

"The State shall not discriminate against any citizen on the grounds of religion, race, caste, sex or place of birth. Therefore, discrimination on the grounds of any of the above issues is prohibited in the country" (MoL, 2010).

\section{BANGLADESH LABOR ACT (BLA) - 2006}

The concept and the method of fixing minimum wage in our country are not well defined in our labor law. It is in practice of the minimum wage board to take references of the other countries before fixing the wage. In the last fixation, the members of minimum wage board visited Cambodia and Vietnam to learn about those countries' practices. The board also took opinions of different stakeholders. Theoretically cost of living, the standard of living, cost of production, productivity, the price of products, business capability, economic and social conditions of the country and the concerned of the locality and other relevant factors are the important elements to consider in minimum wage fixation (BILS, 2016). Section 345 of the BLA states -
"In the determination of the wages for a worker or in fixation of the minimum wages equality irrespective of the sex of the worker, shall be maintained. No discrimination in this regard shall be tolerated by law" (BLA-2006). Practically, we do not find any relevance of these theories declaring minimum wage.

\section{Workers' wages and unrest in the sector}

It was in 2006 when massive unrest for wage revision attracted the attention of national and international forum, and so the government couldn't but formulate and pass "Bangladesh Labour Act- 2006" along with a wage revision fixing Tk 1662 as the minimum wage of this sector. "In spite of all the success stories, the garment sector is jolted with volatility. It faced severe labor unrest for wage hike in 2006. Since then labor unrest took place in the sector almost every year. Records show that almost all incidents of massive labor unrest, which have a direct link with wage hike demand, took place in 2006 and 2010." (The Daily Star, 2012). The movement did not stop in 2010, rather it continued through 2011, 20122013 and it is still continuing. In 2010, after the declaration of revised wage at Tk 3000/00 the Korean company Youngone Ltd reduced the amount to adjust to new wage declaration which was not admissible by the law. The workers of Robin Tex BD Limited blocked the Dhaka-Sylhet Highway and ransacked at least five vehicles alleging that the authorities were not following the new salary scale. The workers of Moazuddin Textile Limited staged demonstrations on the same demand. The factory authorities paid the workers' salary as per the old wage board. They started violent activities protesting the old salary structure. On September 22, 2011 the workers of Square Garments in Kachpur industrial area Naryanganj, demonstrated for a few days demanding the implementation of 16 points, including demands for increased salary and bonus, reduced overtime duty, provision of regular leave, stopping retrenchment of workers, ensuring payment of salary and allowances in due time. They also demanded to the end of oppression and harassment of workers, and the removal of the Managing Director of the company from his post. Workers violence erupted at Ishwardi Export Processing Zone in Pabna on March 26, 2012, for a pay hike. Most of the incidents initiated by the sweater factories. The workers in knitting, linking and trimming sections are under piece rate system. So fixation of rate is a vital issue for workers' unrest.

\section{Wages in different periods, Wage structure and Civil Society}

Over the periods, there have been some revisions in the minimum rates of wages structure for garments workers in Bangladesh. We can have a clear insight into the history of this sort of change in RMG sector from the Minimum Wages Ordinance 1961 which states-

Under the clause (a) of subsection (1) of section 6 of this ordinance and ministry's and the then Ministry of Labour and Manpower, at present Ministry of Labour and Employment) notification no S.R.O 583-L/84/S-X/3(3)/84 dated $26^{\text {th }}$ December 1984, government declared the scale for minimum wage as recommended by the Minimum Wages Board. Hence the minimum rates of wages for the workers of various sections were employed in the garment industries in Bangladesh for the first time on $16^{\text {th }}$ June 1985. 
In its first move government declared minimum wage at Tk $527 / 00$ as the minimum wage for unskilled workers of the sector. In 1994, after almost ten years, minimum wages for the workers of this sector was set at Tk 930/00. In the year $1983 / 84$, the number of export-oriented readymade garments factories was 384. A new trade association named "Bangladesh Garment Manufacturers and Exporters Association (BGMEA)" was formed in 1983 as a common platform of the owners. Within a decade, in 1996, similar body of the knit garment manufacturers "Bangladesh Knitwear Manufacturers \& Exporters Association (BKMEA)" was formed. In the year 1994, that number of readymade garments factories jumped up to 2182. During this period there was no wage structure for the workers of this sector. No regulatory attention from the concerned government authority was visible. Before 1994 there were no wage grades by workers' skills and experience level. Factory management had been fixing the wage at their discretion. Different factories had maintained different policies. The factories in a particular area normally followed a similar range of wages. The payment of the workers was highly dependent on production managers' wishes. In 1994, the industry already reached \$ 1.5 billion export and drew national and international attention due to workers' unrest on different issues mainly on wage. After 11 years of establishment of BGMEA, the first minimum wage board constituted in 1994 had fixed Tk 940 as minimum wage per month for garment workers. To address the criticism from different sections of people, home and abroad, after three years of its first declaration the government re-fixed the minimum wage as taka 1550.00 per month in 1997. Unfortunately, but not surprisingly, the owners of the factories did not accept the government proposal rather they demanded the establishment of a minimum wage board. In July 2001, the government declared a minimum wage structure for the private sector workers fixing 1350 taka as the minimum monthly salary, again the employers rejected the proposal of the Government. A member of the association moved to the High Court, and the High Court declared the government order illegal on technical grounds. (Kamal, Billah \& Hossain, 2010). It took another 12 years to declare the second minimum wage board which was formed in 2006 after workers had to raise their voice and had to show down the same agitation and demonstration to revise their wage. This led the authority to set the minimum wage at TK 1662.50 per month though the workers demanded for TK 3000/00 month. Due to price hike and devaluation of BDT within four years, workers were on the move, and in the year 2010, they got another boost up to taka 3000.00 as minimum wage. A minimum wage board, third of this kind, formed on July 27, 2010, had set the minimum monthly pay at TK 3,000 in August 2010 with effect from November 2010, raising it from TK 1,662.50, even though the workers demanded TK 5,000. Within three years of last minimum wage declaration, they were again on roads. In their fourth initiative after three years' time from the last minimum wage board, a committee of six members was formed in May 2013.
Table 1: Minimum wages in different periods

\begin{tabular}{|c|c|c|c|}
\hline Year & $\begin{array}{l}\text { Minimum } \\
\text { wage(TK) }\end{array}$ & Grade & Remarks \\
\hline 1985 & 627.00 & Unskilled & \\
\hline 1994 & 930.00 & 7 & Basic $\times 30 \%$ HR + MA Tk 150 \\
\hline 1997 & 1550.00 & 7 & Not accepted by the owners \\
\hline 2001 & 1200.00 & 7 & High court declared illegal \\
\hline 2006 & 1662.50 & 7 & Basic $\times 30 \%$ HR + MA Tk 200 \\
\hline 2010 & 3000.00 & 7 & Basic $\times 40 \%$ HR + MA Tk 200 \\
\hline 2011 & $\begin{array}{l}4250.00 \\
\text { (Textiles) }\end{array}$ & 10 & $\begin{array}{c}\text { Basicx } 70 \%, 40 \%, 35 \% \mathrm{HR}+ \\
\text { MA } 300+\text { TA }\end{array}$ \\
\hline 2013 & 5300.00 & 7 & $\begin{array}{c}\text { Basic } \times 40 \% \text { HR + MA } 250 \\
\text { TA } 200 \text { FA } 600\end{array}$ \\
\hline
\end{tabular}

${ }^{*} \mathrm{HR}=$ House Rent, MA = Medical Allowance, $\mathrm{TA}=$ Transport Allowance, FA = Food Allowance

The workers' leaders had placed their proposals to the chairman of minimum wage board formed to fix a fresh minimum wage level of TK 8,114 as monthly wages for the garments workers. According to the proposal, the breakdown of the total amount was TK 300 for clothing, TK 500 for treatment, TK 300 for transportation, TK 200 for recreation, TK 375 for toiletries, TK 500 for festivals and TK 500 for family help to lead standard life. In the proposals, there were seven categories of the workers' minimum wage and 30\% of basic have been proposed as house rent. Initially, BGMEA proposed for TK $600 / 00$ enhancement from the present level of TK $3000 / 00$. The representative of Bangladesh Garment Manufacturers and Exporters Association (BGMEA) Mr. Arshad Dipu proposed a minimum monthly wage of TK 4,250 at the wage-board meeting. After several meetings for a couple of months, the board announced its decision on the majority in consensus TK 5300/00 as minimum wage. The garment owners rejected the minimum wage TK 5,300 fixed by the wageboard members. The board took more than six months' time as it formed in May '13 and published gazette on $5^{\text {th }}$ November 2013. During this period the board had visited Cambodia and Vietnam to know our competitors approaches on wage fixation. There were many debates, proposals, and conferences for consensus to come to an end. But the board failed to take any unanimous decision. The representative from the owners did not sign in the proposed wages. Finally, board proposal was taken on a majority vote. At last BGMEA and BKMEA endorsed the proposal after having a meeting with the honorable Prime Minister on 13 November '13 night. On the other side, even after having an active representation and acceptance by the workers' member this declaration was not endorsed by many of the worker's federations/associations. Still, they are in the streets protesting and vandalizing the factories. A good number of workers are still rigid on their initial demand for taka 8114/00. If we look back in November 2010 while government declared the last minimum wage, fixation to BDT 3000/= from BDT $1,667 /=$; we see that implementation of a minimum wage was a great challenge even after an agreed consensus achieved at that time. In those days the apex bodies like BGMEA/BKMEA firmly declared that they would make sure the implementation of the declaration. They threatened their members if the members did not comply they would lose their membership. That worked and led to proper implementation amid great agitations and vandalism during those days. It will be challenging to implement the declared wage as many already 
termed the present declaration as 'Political Minimum Wage,' and apex bodies' reluctant acceptance came after the publication of gazette.

The minimum wage board declared the latest wage revision for the sector, which set TK 5,300 as the minimum wage for entry-level workers and a $5 \%$ yearly increment of basic salary. This declaration has been effective since $1^{\text {st }}$ December 2013. The basic of the minimum wage has been brought down to TK 3,000 from the wage board proposal of TK 3,200. The new minimum wage saw an increase of $76.66 \%$ compared to the previous minimum wage of TK 3,000. The minimum wage declared by minimum wage board in 2013 is the fourth of this kind. None of the declarations by the wage board resolved the longstanding labour unrest over wages. Owners always see their business losses competitiveness on account of wages hike. On the contrary, workers consider those hike as a small fraction compared to their need. So their life standard remains unchanged owing to the rising rate of inflation, consumer price index, house rent, etc.

Prominent columnists, senior journalists, scholars and veteran educationists, civil society members, independent research institutions like Centre for Policy Dialogue(CPD), Transparency International Bangladesh (TIB), Noble laureate Dr. Muhammad Yunus and many others commented and gave their suggestions on minimum wages in RMG sector. All of them found the logic and industries capabilities to fulfill workers' demand for TK 8300.00 as the minimum wage for the industry. Civil society think tank, CPD recommended TK 6,560 as the minimum wage for an entry-level worker in the country's apparel sector at a dialogue "Revision of the minimum wage in the RMG sector in 2013". A survey conducted by the CPD found a remarkable gap between the monthly salary required and the existing scale. "Labor leaders, parliamentarians from the ruling and the opposition parties and independent experts all backed the CPD recommendation, although some of them demanded more as the living cost has increased tremendously in the recent years" (The Daily Star, 2013).

On the other hand, Transparency International Bangladesh (TIB) commented based on their recent study 'RMG Sector: Problems of Good Governance and Way Forward . According to the study, corruption and mismanagement have taken an institutional shape in the country's Readymade Garment (RMG) industry. Moreover, the industry lacks coordination among the government agencies related to the sector. The corruption watchdog, TIB, emphasized for a separate ministry for the industry to give a big boost to the sector by addressing challenges of occupational and fire safety, compliance issues.

The TIB put forward a 25-point recommendation for establishing good governance and ensuring transparency and accountability in the RMG industry. They also recommended for a separate ministry for this very sector. (The Financial Express, 2013)

Nobel Laureate Prof Muhammad Yunus has made suggested minimum wage to help improve the working and labor condition in the country's biggest industry. In his first proposal, Prof Yunus said foreign buyers should jointly fix a minimum international wage level.
For example, he said if the minimum wage is now 25 cents per hour in Bangladesh, then they will standardize minimum wage for garment industry at 50 cents per hour. "No buyer will give any salary below this rate, and no industry owner will fix salary below this limit. It will be an integral part of compliance" (The Daily Star, 2013).

The leaders of 45 unions of the readymade garment have demanded TK 6, 000 for a minimum wage for the workers excluding food allowance protesting the proposed TK 5.300. They also demanded $10 \%$ increment instead of the proposed $5 \%$ for workers of all grades. As per their demands, the minimum wage for the sweater factory workers must not be less than that of the sixth grade while the wage for per unit has to be declared within three days of starting production. As per their recommendation, the minimum wage TK 6,000 , TK 4,000 as basic, TK 1,600 as house rent and TK 400 as medical allowance. Food allowance has not been included in the basic salary.

\section{DifFERENCES IN W AGE COMPOSITION BETWEen the DECLARATION IN 2010 AND 2013}

In 2010, the composition of gross wage was as basic + House Rent (40\% of basic) + Medical allowance TK. 200.00 for the grade 7 or in helper category it was as below for two different times.

Table 2: Minimum Wage within and outside EPZs

\begin{tabular}{|c|c|c|c|c|c|c|c|c|}
\hline $\begin{array}{l}\text { Non- } \\
\text { EPZ } \\
2013\end{array}$ & $\begin{array}{c}\text { Grade } \\
7\end{array}$ & \begin{tabular}{|c|} 
Basic \\
Wage \\
in \\
BDT
\end{tabular} & $\begin{array}{c}\text { Rate of } \\
\text { Yearly } \\
\text { increas } \\
\text { e in } \\
\text { Basic } \\
\text { Wage }\end{array}$ & $\begin{array}{l}\text { House } \\
\text { rent } \\
(40 \% \\
\text { on } \\
\text { Basic } \\
\text { Wage }) \\
\text { in } \\
\text { BDT }\end{array}$ & \begin{tabular}{|c|} 
Medical \\
Allowanc \\
e (Fixed) \\
in BDT
\end{tabular} & $\begin{array}{l}\text { Conveyanc } \\
\text { e (Fixed) in } \\
\text { BDT }\end{array}$ & $\begin{array}{c}\text { Food } \\
\text { allowanc } \\
\text { e in BDT }\end{array}$ & \begin{tabular}{|c|} 
Gross \\
Minimu \\
$\mathrm{m}$ Wage \\
in BDT
\end{tabular} \\
\hline & & 3000 & $5 \%$ & 1,200 & 250 & 200 & 650 & 5,300 \\
\hline $\begin{array}{l}\text { EPZ } \\
2013 \\
\end{array}$ & Helper & 3600 & $10 \%$ & 1440 & 560 & & & 5600 \\
\hline
\end{tabular}

It is claimed by the employers and minimum wage board that TK 2300.00 and around $77 \%$ of wage has been increased from 2010 declaration to 2013 declaration in grade 7 along with yearly $5 \%$ increment which needs further explanation to understand the inherent facts. According to labour law the benefits, both long term, and short term, from service benefits to overtime calculation everything is based on basic wage. So the board and employers were more cautious about the enhancement in basic. As a result, though taka 2300/00 was increased in total, it was only TK 1000.00 in basic. If a worker gets $5 \%$ increment in a year, his/her annual increment will be TK 150.00 only. They will be losing in overtime and bonus payment. Finally, their service benefits/gratuity, if any, will be lower.

In EPZ, the gross wages are calculated as Basic + House rent $40 \%$ of basic + TK 560 medical allowance. The wage has been fixed in BDT and the equivalent amount of USD which is, for now, TK 80: USD 1 ratio. This exchange rate is subject to change as and when necessary. In addition to above gross wage food or food allowance, transport or transport allowance are being provided by the enterprises. Out-side EPZ annual increment is $5 \%$ of basic while it is $10 \%$ inside EPZs. Outside EPZ wages are calculated according to a seven-step grading system for each job classification based on seniority and experience which is only five-step grading in EPZ areas. Workers doing jobs inside and outside boundary wall of EPZ are sharing the same room in 
Ashulia area, adjacent Dhaka EPZ, with different facilities/ wages for the same nature of the job. This is one of the major reasons behind the recurrent unrest in Ashulia.

\section{From the Gazette of Minimum Wage}

Publication of Bangladesh Gazette on minimum wage for garment sector on 05 May 2013 was the $4^{\text {th }}$ declaration of this kind. But in reality, no one can consider this Gazette is a complete guideline to determine sectors' wage administration. The Gazette itself created confusions and acted as a helping tool of deprivation. In some cases, it seems that the grading system was not well thought and planned. There are so many posts and positions required to run an RMG factory that are not mentioned in the Gazette. It seems that all focus of the Gazette falls on the entry-level workers and their wages. There is no guideline how to measure of workers' competency for a particular grade and how long a worker will be retained in the same grade. These loopholes are helping the employers to manipulate in determining workers' grade. In many cases workers are degraded. On the contrary workers are deprived of overtime benefit, as their position is upgraded for the same nature of job to avoid compulsion of overtime payment.

Under the schedule Kha, i.e. in employee category, there are 4 grades excluding trainee. The period of a trainee will be 6month while this period is only 3-month in trainee workers' category. In grade 4 there are four different posts including Darowan/Checker. In grade 3 there are eight different types of posts where security guard, care taker, driver, time keeper, Cash assistant, typist, telephone operator, clerk etc fall under the same grade. How is it possible to differentiate between the job of a Darowan and a security guard? Grade 2 is about assistant posts like cashier, accounts assistant, store assistant, computer operator export / import assistant and grade 1 is only for store keeper. The department like Human Resource, (HRD) is usually responsible to get the things done which is nowhere in the gazette.

In Schedule Ka, -Workers' category. There are 7 different grades excluding trainees. In grade 7 there are fourteen different posts like overlock machine assistant, finishing assistant, line iron man/woman, pocket creasing machine operator etc. who fall under the same grade which is confusing. The job of an over lock machine assistant and the job of sewing machine assistant is not same. The post of line iron man/woman is not appropriate here in grade 7 . Their status should be higher. Pocket creasing machine operator is a process operator so they will be graded in upper range. Grade 6 is about general posts. The Grades $6-4$ are the posts of general operator - junior operator - operator. Industry experts find the sequences of those terminologies not properly arranged. It could have been like junior operator - Operatorsenior operator. It might have been necessity to add one more grade in operator category. It is difficult to differentiate the functions of a general operator and operator. It is confusing to many that why general operator is behind a junior operator. In grade 5 there are the posts of junior operators, Junior Packer, junior electrician, junior pressing man/woman, junior cutter etc. for a packer who is to assort the garment based on size, purchase order number etc. needs education. The post junior electrician also requires expertise in his filed, so this could be considered for upper grade. The job of junior pressing man/woman could be considered from grade 6 instead of grade 5. Grade 4 is of operator, cutter, marker/drawing man/woman, quality inspector, poly man/woman, line leader etc. Experts find this grade with more inconsistencies. The function of a poly man/woman is the simplest operation among others, on the other hand, the post of line leader is equivalent to line chief or supervisor. So their job should be in higher position. Machine operator and quality inspector should not be in the same grade. Grade 3 is about senior operator, mechanic, sample man, senior quality inspector, senior over lock machine operator, senior button machine operator. An owner and expert in operation commented that this grade has mixed up with a car mechanic and aircraft mechanic. The job of a button machine operator is the easiest operation. One person marks the position of the button and the operator maintains the placement. The job of a senior quality inspector should not be in the same position of a senior operator. Quality inspection is the most challenging and requires education and specialized skills. The position of mechanic should be much higher than senior operator. Grade 2 consists of mechanic/electrician (the post of mechanic was already mentioned in the grade 3 which creates ambiguity) and cutting master. The job of an electrician in a garment industry is a kind of routine work. But the job of a mechanic is more complex work, and there is variety with challenges. So mechanic and electrician should not be in similar grade.

There are some more findings on wage declaration which has been mentioned as below.

Discrimination - The declaration of any new wage structure always focused on entry-level workers which is a very minimum fraction of total. The rest of the grades are not benefited as grade 7 . The workers who are more experienced get a little out of this kind of wage hike.

Manipulation - A manipulative wage enhancement policy like keeping the basic wage as low as possible and add bonuses or incentives to show the gross wage a big chunk. This was clearly visible in last minimum wage fixation. Moreover, factory management changes the designations in disguise to promotion like executive, supervisor etc. to keep them away from OT benefits, who are getting comparatively higher wage, to prove that those are out of grade.

Table 3: Different Grades and Overtime (OT) benefits

\begin{tabular}{|c|c|c|c|c|c|}
\hline \multicolumn{3}{|c|}{ Workers } & \multicolumn{3}{|c|}{ Employees } \\
\hline GRD & Designation & REMARKS & GRD & Designation & REMARKS \\
\hline 7 & $\begin{array}{l}\text { Assistant/ } \\
\text { Helper }\end{array}$ & OT & 4 & $\begin{array}{l}\text { Cleaner/Loader/ } \\
\text { Office Assistant }\end{array}$ & OT+FIXED \\
\hline 6 & General & OT & 3 & Guard & FIXED \\
\hline 5 & Junior & OT & 2 & Store Assistant & FIXED \\
\hline 4 & Operator & OT+FIXED & & & \\
\hline 3 & Sr. Operator & OT+FIXED & & & \\
\hline 2 & Electrician & FIXED & & & \\
\hline
\end{tabular}

Degradation: After the declaration of minimum wage in 2010, many factories rearranged their grading system- one step down than actual grade, since there was no method of selecting or fixing the grade and keeping the workers in the same grade years after years. Reassigning them to lower pay grades meant that they did not receive the full increase to which they were entitled. There was no system in place to promote a worker who would be expected based on their skills and experiences. 
Overtime: Overtime work at least for two hours is common in the sector. But most of the factories need more OT work to meet the delivery schedule. Many workers do not know the correct method of OT payment calculation. They depend on supervisors. All the time workers do not keep the record of total OT hours. Sometimes, there is a mismatch between the factory record and workers' record.

Deduction of wages: Deduction from wage is a common tool as punishment for five minutes late. If any worker fails to report in time for three consecutive days, one-day salary/wage will be deducted. Deductions from wages or cutting OT hours are very common practice used by the factory management.

\section{AN EMPIRICAL EVIDENCE AND WORKERs' Productivity}

A woven tops factory with 15-line production capacity has 2500 manpower without the areas like marketing and merchandising, accounts, commercial and information technology. Out of total 2500 only 1913 is in workers grades (grade 1 to 7 ) and rest of the manpower is in employees grades (grade $1-4$ ). The highest numbers, total 456, of workers are in grade 7 i.e. entry level, as a helper. According to the declaration in 2010, the minimum wage was fixed at TK 3000.00 for this grade but only $50 \%$ i.e. 231 workers are getting this minimum wage. The rest $50 \%$ are getting TK. 3100.00 to TK. 4300.00 which is more than grade 3 wage (TK. 4218 in grade 3). Though wage enhancement in 2013 for the grade 7 was $76.67 \%$, from TK. 3000.00 to TK. 5300.00 but it was only $59.40 \%$ for this factory. Total 375 workers are in grade 6 , general operator. Almost $100 \%$ of workers in grade 6 are getting more than their minimum wage level of TK. 3322.00. Most of them are getting TK. 4000.00 and few of them are getting TK. 5100.00 . TK 5678.00 from TK. 3322.00 is $70.92 \%$ increased but it was only $43.22 \%$ increased for the factory. The factory has 420 workers in grade 5 , junior operator and their minimum wage is fixed at TK. 3553.00 which is now TK. 6042.00 i.e. $70.05 \%$ increased. The grades from assistant to junior operators consist 65\% i.e. 1251 of total workers 1913. With this reality, it is easy to understand the efficiency of the factory because of more number of unskilled workers.

It is well known that the wages in Bangladesh are among the lowest of the world. Actually every factory has over employment than required at the same time all of them lack of efficient workforces. A 10-line knit production unit can easily run with 500 employees but they are paying for 750 to 780 employees. If the factory could employ as minimum possible workers with required efficiency then wages of 780 employees would be distributed among 500 workers, everyone would be happy. It is obvious that no management will increase salary/wages if the factory is not running profitably. The sector's productivity and efficiency are much lower than its competitors' countries. Every factory has to hire at least $20 \%$ workers more to support their expected production due to inefficiency of the workers.

\section{WAGE HIKE AND ITS IMPACT ON BUSINESS}

A magic of percentage - It sounded good when there was an announcement of increased wage by $80.45 \%$ from 2006 to 2010 i.e. in grade 7 TK. 1662.50 to TK. 3000.00 . In the other grades,
Wages increased by $67 \%$ to $81 \%$, depending on job categories. There is a tendency to announce wage increase in percentage rate and at the very first, knowing that percentage, it seems to be enough and logical to anyone. It will be fair to announce their wage enhancement in figure along with percentage. Workers' minimum wage is minimum compared to other costs that a $100 \%$ increase can't ensure their living wage. Only with the magic of "percentage" workers' living standard can't be ensured.

Exchange rate gain- The payment they receive is in foreign currency, usually in USD and the payment they make to the material supplier is also in foreign currency. The bank transfer the balance amount, as instructed by the parties, to their current $\mathrm{a} / \mathrm{c}$ at the exchange rate of that particular date. In the year 2013, the lowest rate was at TK. 78.00 and the highest rate was TK. 85.00. The exporters have gained TK.7.00 against every single USD. It was known that many of the factories have paid their wages from their gained exchanged rate, keeping CM earnings un- touched. But workers had to buy paying more for the same products of their basic need. Who loses, who gains?

Reduced Cutting and Making (CM) charge- During '90s it was around $\$ 22 / \mathrm{dz}$ in US market as manufacturer had to buy quota for the particular category and it was around $\$ 14 / \mathrm{dz}$ in Europe for the same product. After 20 years of quota free market, the price has come down to $\$ 12.00$ - \$15.00 (Approximately) in both the destinations. With the increased wages, utility charges it is difficult for the factories to adjust with current $\mathrm{CM}$ charges. To address any economic meltdown and recession in importing countries, they cut the labor cost which is a very small portion (around 15\%) of total business. Interestingly, within the period the rate of subcontract for the same product has increased at least three times higher. It was TK. 25.00 / pcs in 2000 which was TK 50.00 - 70.00 in 2017.

An imbalanced balance sheet - The workers of the industry vandalize their own workstation and putting halt to work to materialize their demand. The owners are refuting workers' demand saying the industry will die if they have to increase the wages. Many readymade garments have readymade balance sheets to prove their negative growth. Interviewing with the workers and federation leaders it was known about the growth of the companies during the last decades. One leader in mediocre position said "Sir, see the buildings, 10 years ago he (owner of the building) started his factory in a rented building with old machines, with 2 lines capacity. He was an employee where I had been working, and that two lines factory is now a group of companies." He added, "Our workers can't afford to buy basic protein, can't visit a doctor, but the factory owners are becoming richer day by day. They are busy with architect, interior designers to give new look to their residence but careless about factory building where poor people generate their income." He was emotional while talking "The garment workers demonstrate for an adjustment to the minimum wage because of essentials price hike, sudden increase of house rent, for safe working condition, weekly holiday and to protest against harassments. In return workers receive termination, wage deduction, threat and so on". He continued saying "They have money so they have everything. They do not need to see reasonable ground and compensation 
procedure as per the provisions of labor law." One senior official expressed his outrage and told "Most of the time their owners stay abroad, to see their children, who have been studying in Europe, America or in Asian countries like Malaysia, Thailand, and Singapore. They live their life in ultramodern houses in the posh areas of the city, change their car model every year but always are in cash shortage when there is any issue on workers' benefit." He continued "We are here to "manage" our workers, our auditors, they are reluctant to spend money for the fulfillment of rational, legal requirement but will be angry with us if it fails in compliance audit." The number of garment factories were 2182, 4490 and 5150 in the FYs 1994 /95, 2006/07 and 2010/11 respectively. The figures show the geometric growth of the industry. Then how come they are running their factories on loss? Why workers cannot be a part of that growth of the industry? Workers do not trust their employers. Mutual trust and respect are absent while cordial relationship is beyond imagination. With the prevailing situation it is extremely necessary to build a congenial atmosphere so that workers have no chance to be arrogant. To do so employers have to come forward. False statement or fake balance sheet may help in reducing government tax but it intensifies antagonism among the workers.

It's a blame game - Manufacturers claim that buyers are not paying as much as to cope with the increased costs including wages. Moreover, to meet the new requirement of compliance, factory owners are depending on bank loan at higher interest rate. On the contrary, workers observe the geometric growth of their companies they work for. If the buyers do not pay and the owners do not make profit then how this immense growth has been there within a decade? How a small factory in a rented building turned into an industrial park? It is difficult to make one understand that buyers or brands are not offering fair price but it is easy to justify that the entrepreneurs are making profit out of their businesses. A simple but very conservative calculation can help us to understand the game behind the blame.

A factory, woven tops, produces 1000 pcs of garments in one line using 100 men. It will be total 26000 pcs of garments in one month considering 26 working days in a month. If the price per piece garment is taka $100 / 00$ then total earning in a month from a single line would be TK 26,00,000.00. Considering average wage is TK. $10,000 / 00$ per month, total wages for 100 workers would be TK. 10,00,000/00. Adding the same amount TK $10,00,000.00$ as others cost gross total cost would be TK. 20,00,000.00. There are even TK. 6,00,000.00 balance from each line each month.

Pareto's Principle, 80 -20 rule -Italian economist Vilfredo Pareto who observed in 1906 that $80 \%$ of the land in Italy was owned by $20 \%$ of the population. From his observation, Pareto developed the principle that $20 \%$ of the pea pods in his garden contained $80 \%$ of the peas. This $80-20$ rule is more relevant in RMG sector as well. In this industry, 20 percent of non-worker class employees are eating up 80 percent of total wages. To the contrary, 20 percent wages are being distributed among the 80 percent workers. This exploitable ratio has been continuing due to shortage of skilled and experienced mid to top level management. It was reported in the media that the CEO of Wal-Mart Mr. Michael Duke was paid \$ 1.3 million, excluding bonuses, as his salary in the year 2011. The total compensation for that year for the CEO was \$17.6. A factory with more than 2000 workers and paying around TK 2.00 crore as wage is carrying the following percentage.

Table 4: Wage gaps among the different designations

\begin{tabular}{|l|l|l|l|l|}
\hline Position & $\begin{array}{l}\text { Total } \\
\text { Workers }\end{array}$ & $\begin{array}{l}\text { Total wage } \\
\text {-BDT }\end{array}$ & Average & Percentage \\
\hline Total 396 (grade 7-2) & 1951 & 14080171.00 & 7217 & 11 \\
\hline $\begin{array}{l}\text { Non Grade } \\
\text { (Supervisor-Sr. Officer) }\end{array}$ & 246 & 3412774.00 & 13,873 & 21 \\
\hline $\begin{array}{l}\text { Managers } \\
\text { (Jr-Sr Managers) }\end{array}$ & 38 & 1658620 & 43,647 & 67 \\
\hline Total & 2202 & 19151565 & 64737 & 100 \\
\hline
\end{tabular}

Cost cutting and risk freeing policy by the buyers -From the very initial period to recent past irrevocable at sight Letter of Credit (L/C) from the buyers' side to manufacturers' company was mandatory which is called the master $\mathrm{L} / \mathrm{C}$. keeping lien that L/C copy manufacturers' bank opens Letter of Credit in favour of suppliers companies to procure raw materials for the finished products which is called Back to Back (BtB) L/C. To open any (master) L/C, it requires cash or equivalent guarantee in the bank by the buyer. According to ICC (International Chamber of Commerce) clause any irrevocable L/C can't be cancelled without both parties' agreement. And it is an obligation for the L/C opening bank to the beneficiary's bank for payment if the document of the export consignment is accepted. So to open a L/C both master and $\mathrm{BtB}$, equivalent cash or kind is required. To avoid that cash involvement, to reduce cost as L/C opening charges and finally to minimise risk, many of the big buyers (importers and brands) have introduced new way of buying. Instead of L/C, they are buying under sales or purchase contract, an agreement between a buyer and a seller. On the other hand, our manufacturers are selling their merchandise with 90-180 days sight i.e. at deferred payment. Many buyers are paying their suppliers after selling their products. So buyers are saving money i.e. earning more money applying both the tools, sales contract and deferred payment. On the contrary, as a buyer of raw materials Bangladesh's manufacturers can't buy under contract neither from domestic suppliers nor from international suppliers. So their cost and risk in this regard remain the same as it was in initial stage.

Unplanned Growth -The growth of RMG sector in our country was not the outcome of long term planning of neither the government's nor the entrepreneurs' level. When international policy support came in favor of Bangladesh, new entrepreneurs found the opportunity as a quick means to be rich. And government helped keeping its regulatory mechanism silent and inactive for the sake of employment generation. There was no way to accommodate huge number of workers unemployed due to loss of international market of Jute and Jute products. Till early ' 80 s about $80 \%$ of the world's jute used to be produced in Bangladesh, earned 68\% foreign exchange. The share of jute and jute products export came down to $6 \%$ in 1990-91. To the contrary, in 1984 the number of export oriented readymade garments factories was 384 and in 1994 that number jumped up to 2182. Not only in numbers, the size and capacity of the factories have been increased not analyzing and considering market trend, strength of the competitors, and the consequences of any disaster, national or 
international, natural or human-made. To run a factory of woven tops with fifteen lines capacity it needs 1265,200 pcs (based on 85 pcs per line/per hour x $8 \times 26 \times 15$ ) per month. When any projected capacity, for any reason, is withdrawn by the buyer then it's a big challenge to make it up by another buyer. Then the factory offers lower CM charge as possible to run the machines to minimize the losses. The factory owner's emphasis on running the production lines as always. When there is a gap between total required business volume and total available business, sometimes the buyers artificially create a situation where an unhealthy competition starts among the factory owners. Everybody wants to ensure his/her capacity fulfilled first. If anyone asks for $\$ 12 / \mathrm{cm}$, others offer the buyer $\$ 11 / \mathrm{cm}$ which is sometimes less than cost price. It is pity that if any maker refuses to take work order due to lower price, others are ready to grab that orders even for less than the offered price. In an interview with Reuters an owner explained his situation "For one recent order, the company generated a net loss of 2.42 percent of the sales value, the documents show. A similar order placed before the wage hike generated a net profit of 2.69 percent of sales value". With the reduced CM and increased demand on Code of Conduct (CoC) how it is expected that the workers will be well paid?

\section{CONCLUSION}

In private sector, especially profit making undertakings have the declarations of minimum wage for the different industries. The rate of minimum wages varies across the countries and according to nature of industry within the country. There are many countries which have different minimum wages for the same sector depending on regions like Vietnam, China etc. There are countries that have only one national level wage like Cambodia. There are also other countries which have no declaration of this kind. In India, where more than 1200 minimum wage rates while there is no minimum wage declaration in Myanmar. Countries like Sri-Lanka, India, Pakistan, and Bangladesh have separate minimum wage legislation. But the countries like Cambodia, China and Vietnam do not have any legislation on minimum wage but have minimum wage provisions laid down in the labor code. Profit maximization is one of the prime objectives of any investor in commercial sector. Workers' movement for wage hike is historical and worldwide. The term "Minimum Wage" was not very common in Bangladesh, before the RMG industry evolved in such a shape and size, though a minimum wage board exists since 1958 .

RMG industry in Bangladesh, so far has been enjoying a very clear price competitiveness against its' competitors in China, Vietnam or India. At the same time, Bangladesh is far behind in other parameters like political stability, lead time, efficiency etc. The competitiveness on price due to low wage is going to be narrowed down significantly as the prices of essentials are getting two digits up. Bangladesh RMG industry is still in basic products and lower segment in business value chain. To cope with wage hike and low price offered by the buyers, the sector needs a move to next value addition stage i.e. fashion designing. Mere increase on wages doesn't guarantee the well-being of the workers in their daily lives. It has been experienced that any announcement of new pay scale, increases the prices of daily commodities instantly. The declaration of the national budget every year in the parliament, automatically legs up the market prices of almost everything that sells in the market including the daily consumables. If it is so, then what is the use of this revision of wages? Probably it would have been more useful if the workers could raise their voices to curb the unreasonable price hike in the market of commodities and services. Steady market price with enhancement of wage only can benefit the workers. Otherwise, workers' movement will remain a mere formality from time to time eventually achieving almost nothing out of it.

\section{REFERENCES}

Ahmed, N., Nasima, M., \& Alam, N. (2013). Socio-Business Consideration of Garment Workers in Bangladesh: A Statistical Review. ABC Journal of Advanced Research, 2(2), 83-92.

Aktar, M. (2014). Green Insights of Textile Industry in Bangladesh: A Case Study on Mozart Knitting Ltd.. Global Disclosure of Economics and Business, 3(1), 93-108.

Bhuiyan, M. I. (2013). Reasonable Wages for Workers to Eliminate Unrest in Bangladesh's Ready-made Garments (RMG) Sector. University of Chittagong. Bangladesh Development Research Working Paper Series (BDRWPS) BDRWPS 17

BILS (2016). Labor. A (Bangladesh Institute of Labor Studies) BILS Journal, July - December 2016, Dhaka

Chowdhury, S. (2015). The Necessities of HR practices in RMG Sector of Bangladesh. Global Disclosure of Economics and Business, 4(1), 7-20.

Citizen Charter, Minimum Wage Board, Ministries of Labour \& Employment, Govt. of Bangladesh.

Fair Wear Foundation -Bangladesh Country Study 2013.

Hasan, M. (2017). Supply Chain Management in Readymade Garments Industry, Bangladesh. Asian Business Review, 7(3), 103-110.

Hasan, M. (2017). Wage Digitization in Readymade Garment (RMG) Sector in Bangladesh is Crucial for Women Empowerment, Social Compliance and Competitiveness. Engineering International, 5(1), 37-44.

Hossain, T., \& Shirazi, H. (2018). Quality of Work Life among Women Employees Working in RMG Sector of Bangladesh. Global Disclosure of Economics and Business, 7(1), 27-40.

ILO (2017) C026- Minimum Wage-Fixing Machinery Convention, 1928

(No. 26)

http:/ /www.ilo.org/dyn/normlex/en/f?p=NORMLEXPU B:12100:0::NO::P12100_ILO_CODE:C026

ILO (2017) C131- Minimum Wage-Fixing Convention, 1970 (No. 131)

http:/ / www.ilo.org/dyn/normlex/en/f?p=NORMLEXPU B:12100:0::NO::P12100_ILO_CODE:C131

ILO, 2018. World Employment and Social Outlook - Trends 2018 http://www.ilo.org/wcmsp5/groups/public/--dgreports/ --dcomm/--publ/documents/publication/wcms_615594.pdf 
Kamal, M., Billah, M. M. \& Hossain, S. (2010) Labor Unrest and Bangladesh Labor Act 2006: A Study on Ready Made Garment Factories in Gazipur. Volume- V, Issue- 02, July-Dec

Korde, R. -Economics Area. Asian Countries Wage Indicator Minimum Wage Report Series 01 June 2012 Official Representation of Minimum Wages.

Minimum Wage Implementation in Bangladesh's Garment Sector. A research study conducted by Alternative Movement for Resources and Freedom (AMRF) Society with the support of Fair Wear Foundation June 2012.

Minimum Wages Act, 1948.

Mirdha, R. U. (2012): Causes of RMG Unrest. Forum, A monthly Publication of Daily Star, Volume 6, August 2012.
Roundtable on 'National Minimum Wage: Poverty Reduction and Social Justices for Workers' on August 24, 2006.

Tania, F., \& Sultana, N. (2014). Health Hazards of Garments Sector in Bangladesh: The Case Studies of Rana Plaza. Malaysian Journal of Medical and Biological Research, 1(3), 113-120.

UDHR, 1948. Universal Declaration of Human Rights http:/ /www.un.org/en/universal-declaration-human-rights/

Varkkey, B. -Personnel and Industrial Relations Area, Indian Institute of Management Ahmedabad,

Wage Indicator Minimum Wage Report Series 01 June 2012.

$$
--0--
$$

How to Cite: Hasan, M. (2019). Minimum Wage in Readymade Garments Industry in Bangladesh. American Journal of Trade and Policy, 6(2), 57-66.

\section{SOCIAL SCIENCE RESEARCH NETWORK \\ 2171 Monroe Avenue, Suite 203, Rochester, NY 14618, USA http://www.ssrn.com/en/} SSRN Link: http://www.ssrn.com/link/American-Journal-Trade-Policy.html 